DOI 10.15290/cnisk.2020.02.09.09

YULIA GRADSKOVA

https://orcid.org/0000-0002-0975-5560

Stockholm University and Mid-Sweden University

\title{
The cold war and the Women's International Democratic Federation: defending women's rights and inspiring women with achievements of the state socialism?
}

\begin{abstract}
This paper is dedicated to the history of the Women's International Democratic Federation (further WIDF), the influential transnational organization of the period of the Cold War. The scholars who were dealing with the history of this organization have different opinions about its activities and historical role. Indeed, several researches have shown that the federation realized a lot of solidarity work; the federation was important not least with respect to the anti-colonial and anti-racist struggles as well for cooperation between women from inside and outside Europe ${ }^{1}$. But on the other hand,

\footnotetext{
1 Francisca de Haan, "Continuing Cold War Paradigms in Western Historiography of Transnational Women's Organizations", Women's History Review, Vol. 19, No. 4, 2010, 547-573; eadem, "The Women's International Democratic Federation (WIDF): History, Main Agenda and Contributions (1945-1991)", in: Thomas Dublin, Kathryn Kish Sklar (ed.), Women and Social Movements (WASI) Online Archive, 2012, http://alexanderstreet.com/products/women-and-social-movements-international; eadem, "The Global Left-Feminist 1960s. From Copenhagen to Moscow and New York", in: The Routledge Handbook of the Global Sixties, (London : Routledge, 2018), 230-242; Kristen Ghodsee, Second World, Second Sex, (Durham : Duke University Press, 2018); Katharine McGregor, "Opposing Colonialism: the Women's International Democratic Federation and Decolonization Struggles in Vietnam and Algeria 1945-1965", Women's History Review, Vol. 25, No. 6, 2016, 925-944.
} 
historically this organization was seen as dependent from the Soviet Union ${ }^{2}$ or as the organization where Communist ideas and Soviet bloc's geopolitical interests have played an important role ${ }^{3}$.

The aim of this paper is to explore some of the contradictory aspects of the WIDF's ideology and activities. I use the WIDF's official publications, first of all, the federation's journal Women of the Whole World/ Zhenshchiny mira (published from 1951 in English, French, Russian and, later on German, Spanish and Arabic) vis-à-vis the material from the archive in Moscow, belonging to the WIDF's member organization from the Soviet Union (GARF, Fond of the Committee of the Soviet Women).

In this paper I discuss the federation's use of the achievements of the state socialist countries on the way to women's emancipation as well as WIDF's main political concepts and some of their interpretations. Thus, I explore the contradictions with respect to how the concepts as human rights, democracy and women's rights were used in WIDF's documents from different periods as well as discuss conflicts connected to their use.

Keywords: Cold War, women's rights, Women's International Democratic Federation, Women of the Whole World, socialist propaganda

\section{ZIMNA WOJNA A ŚWIATOWA DEMOKRATYCZNA FEDERACJA KOBIET: OBRONA PRAW KOBIET CZY PRZEKONYWANIE ICH DO ZDOBYCZY PAŃSTWOWEGO SOCJALIZMU?}

\section{Streszczenie}

Artykuł poświęcony jest historii Światowej Demokratycznej Federacji Kobiet (ŚDFK), wpływowej międzynarodowej organizacji okresu zimnej wojny. Badacze zajmujacy się jej funkcjonowaniem prezentują zróżnicowane opinie na temat działalności i roli historycznej federacji. $Z$ dotychczasowych ustaleń wynika, że ŚDFK oprócz inspirowania Europejek i kobiet

2 Roger Kanet, "Soviet Propaganda and the process of national liberation", in: Roger Kanet (ed.), Soviet Union, Eastern Europe and the Third World, (Cambridge : Cambridge University Press 1988), 84-114.

3 Celia Donert, Whose Utopia? Gender, Ideology and Human Rights at the 1975 World Congress of Women in East Berlin, in: Jan Eckel, Samuel Moyn (eds.), The Breakthrough: Human Rights in the 1970s, (Philadelphia : University of Pennsylvania Press, 2014), 68-87. 
z pozostałych kontynentów do walki o ich prawa realizowała wiele projektów solidarystycznych. Niektóre $z$ jej inicjatyw miały wpływ zarówno na proces dekolonizacji, jak i postępy w walce $z$ rasizmem. Jednocześnie organizacja była postrzegana jako zależna od Zwiazku Sowieckiego, jako struktura propagująca idee komunistyczne i geopolityczne interesy bloku wschodniego.

Celem tego artykułu jest zbadanie pewnych sprzeczności pomiędzy baza ideologiczna a praktyczną działalnością ŚDFK. Podstawą do opracowania tematu sa $z$ jednej strony publikacje zaczerpnięte $z$ oficjalnego organu prasowego federacji, którym od 1951 r. był periodyk „Kobiety Całego Świata" (ukazywał się w języku angielskim, francuskim, rosyjskim, a później niemieckim, hiszpańskim i arabskim), a $z$ drugiej strony materiały zrzeszonego w ŚDFK Komitetu Kobiet Sowieckich (dostępne w zasobie Archiwum Państwowego Federacji Rosyjskiej, w zespole Komitetu Kobiet Sowieckich).

$\mathrm{W}$ artykule scharakteryzowano główne koncepcje polityczne ŚDFK, jak też skalę wykorzystania do celów propagandowych przez federację osiagnięć państw socjalistycznych. Ukazano też poprzez pryzmat oficjalnych dokumentów federacji $z$ różnych okresów jej działalności zmieniające się interpretacje takich pojęć, jak: demokracja, prawa człowieka, prawa kobiet oraz wynikłe $z$ tego sprzeczności zwiąane $z$ użyciem tych terminów.

Słowa kluczowe: Zimna wojna, prawa kobiet, Światowa Demokratyczna Federacja Kobiet, „Kobiety Całego Świata”, propaganda socjalistyczna

\section{The life of women in the countries of state socialism as an example for "sisters" from other countries}

The WIDF had own periodical publication - Women of the Whole World/ Zhenshchiny mira - a journal that, according to its title, was aimed for explaining the WIDF's mission to women in different countries. It is remarkable that all the materials published in this journal that were dealing with the countries of state socialism usually presented a very positive picture of the situation with women's rights there. Indeed, the "problems" with women's rights, according to the WIDF, mainly concerned women living in the "capitalist" countries or in the countries in Africa, Asia or Latin America.

While analysis of different representations of state socialist emancipation of women on example of the WIDF's official publications can constitute a study of its own, here I want to pay attention only to a part of the representation of "happy socialist women" used as an example for 
women in other parts of the world. In particular, a big amount of materials was dedicated to the Soviet emancipation of women in the Central Asia, an important region for demonstrating the achievements of the Soviet modernity to the outside world ${ }^{4}$. Indeed, this region was considered to be populated by women who in the past were fully dominated due to religious traditions and lack of education. Thus, the emancipation of the Central Asian women was one of the important achievements of the Soviet modernization ${ }^{5}$. The number of articles on the Soviet non-Russian republics (borderlands, according to Tlostanova ${ }^{6}$ ) in the WIDF journal increases in the late 1950s-early 1960s, the period when anticolonial struggle in Africa and Asia and women's participation in it moved into the center of the international attention.

For example, in 1959 the journal published the article by Maria Theresa Gallo "Today, a Woman is a President of the Republic of Uzbekistan" . The article compares the situation of women before the October revolution with their present day social roles and rights. Indeed, Ms. Savekova, who occupied the position of the minister in the Uzbekistan's government remembered the "old time" when she was: "married as millions of other young girls on the decision of her parents, and seeing her husband for the first time on the wedding day"s.

According to the article, the women of the Soviet Uzbekistan were widely represented in the Supreme Soviet while one of them serves as its president. The author also stressed that women comprised $40 \%$ of the student population ${ }^{9}$.

The issue of Zhenshchiny mira (in Russian) from the same year published a long article on a Kyrgyz woman, Kerimbyubyu Shopokova, who was a delegate of 11 th CPSU congress and the member of the Supreme Soviet - Two gold stars. Shopokova was presented as a person

\footnotetext{
4 More about the role of the Central Asia and Tashkent, in particular, in the propaganda of Soviet modernity see: Rossen Djagalov, Masha Salazkina, "Tashkent '68, a cinematic contact zone", Slavic Review, Vol. 75, No. 2, 2016.

5 Yulia Gradskova, Soviet Politics of Emancipation of Ethnic Minority Woman, (Cham : Springer, 2018).

6 Madina Tlostanova, Gender Epistemologies and Eurasian Borderland, (Basingstoke : Palgrave, 2010).

7 Maria Theresa Gallo, "Today, a Woman is a President of the Republic of Uzbekistan", Women of the Whole World, No. 2, 1959, 9-21. This article was published in both English and Russian version of the journal.

8 Ibidem, 20.

9 Ibidem, 21.
} 
of a humble origin coming from a peasant family in the mountain region of Kyrgyzstan. At the same time she was a widow of a WWII hero: her husband heroically died defending Moscow. In spite of this tragedy Shopokova was shown in the article as an active and successful woman: she worked with planting the sugar beets and was an exceptionally good worker. Shopokova also took part in the political life, not least, was sent to represent Kyrgyzstan in the Soviet governing bodies, to Moscow ${ }^{10}$. The article suggested that the Soviet Union opened new opportunities for career and political and cultural participation to all the women living on its territory without making differences with respect to race, ethnicity or former colonial/ metropoly status of the territory.

The article from 1963 signed by Layla "I have seen, I have heard, I have learnt," informed the readers about the seminar dedicated to the education of women in Africa that took place in Tashkent in $1963^{11}$. The author compared the "old" (pre-1917 Tashkent) to the "new" one and stressed that in difference to the period when Tashkent was a colonial city, contemporary one "has become one of the largest industrial and scientific centers of the Soviet Union with a balance-sheet in the educational field alone with a hundred and fifty secondary schools, over forty schools for working youth, sixty higher schools of learning, including the Central Asiatic State University and the Conservatoire"12.

In her article Layla also described her meeting with one of the "new Soviet Uzbek woman", Yagdar Nasriddinova (in spite being the head of the Supreme Soviet Nasriddinova was presented in the article as a President of the Uzbekistan). According to the article, "charming" and "intelligent" Nasriddinova met delegation of women from Africa who came to Tashkent in order to take part in the seminar on women's education and stressed importance of women's common actions: "hundreds of kilometers separate us from you, but one goal unites us all: the preservation of peace in the world. With the new technological developments all peoples can be happy"13.

These examples (just few from a big number of other that could be found in the WIDF journal) demonstrate that the WIDF actively and

\footnotetext{
10 "Two gold stars", Zhenshchiny mira, No. 2, 1959, 10-11.

11 Layla, "I have seen, I have heard, I have learnt", Women of the Whole World, No. 1, 1963, 11-13.

12 Ibidem, 9.

13 Ibidem, 13.
} 
uncritically used not only the Soviet rhetoric on the happy life of the Soviet women who have all the rights, but also the Soviet stories on emancipation of "women of the East." As it is already studied, the Soviet narrative did not pay much attention to the problems, limitations and imperial discourses accompanying such an emancipation (see critique of the Soviet emancipation of women in the Central Asia and ethnic minority women ${ }^{14}$ ).

The articles on other countries of the Soviet bloc also presented both achievements of the state socialist system with respect to women's rights and readiness to share positive experience with their "sisters" from other countries. The idea of "sisterhood" between women that was problematized by Chandra Mohanty with respect to Western feminism ${ }^{15}$, seems to be used similarly uncritically in the WIDF's publications like in those by the Western feminists. For example, the issue from 1959 published article by Madlen Drbalova "Foreign students in Czechoslovakia" that described not only good conditions for female international students in this country, but also friendliness of the city itself and gratitude of the students from the different countries in the Global South ${ }^{16}$. Furthermore, the issue from 1961 by WIDF's Secretary, Odele Arrighi described the festival on protection of motherhood that took place in Romania: the guests from several Asian and African countries were shown how the state socialist care on mothers is organized in Romania ${ }^{17}$. Thus, the article suggested that the women from newly independent countries in Asia and Africa inspired by this example should follow it in their work locally. In issue from 1975 published journal article on new family Code in Hungary ${ }^{18}$ that also was supposed to serve as an example of the achievements of the state socialism that women in other countries should follow.

\footnotetext{
14 Marianne Kamp, New Woman in Uzbekistan, Islam, Modernity and Unveiling under Communism, (Seattle : University of Washington Press, 2006); Yulia Gradskova, Soviet Politics of Emancipation.

15 Chandra Mohanty, Feminism Without Borders, (Durham : Duke University Press, 2003).

${ }_{16}$ ZM 1959, issue 7, pp. 23-26.

17 ZM 1961, issue 2, pp. 5-6.

18 WWW 1975, issue 3, pp. 48-49.
} 


\section{WIDF as a "democratic organization" and problems with the internal democracy}

As it is possible to see, the WIDF had the word "democratic" in the organization's title. Also many of the federation's early member-organizations usually had the word "democratic" in its title (for example, The Democratic Union of Cuban Women - member of WIDF before the reorganization after the Cuban revolution, in 1960; The Democratic League of Finnish Women - 1944-1990, etc). Thus, it is possible to say that the word "democracy" and "democratic organization" were very central for those working for and with the WIDF.

The correspondence preserved in the archive in Moscow indicates that during the Cold War period the WIDF was trying to convince women that, in difference to the "bourgeois" women's organizations including the most famous transnational ones (ICW, WILPF), only the women's organizations that are the members of the WIDF can we considered really democratic. For example, in her reflection about WIDF's activities, Carmen Zanti, the WIDF's General Secretary in early 1960s, stressed that women in different countries frequently started to be active and attempted defending their rights and organize themselves because they have common problems, not least, those connected to their status as "working women." However, in the case of lack of available information about the WIDF they could join "other (international) organizations" (not the WIDF). However, according to Zanti, only the WIDF was a true "democratic organization", that is why working women should join it (and not other organizations) $)^{19}$.

Nevertheless, the documents show that later Zanti started to look more critically towards the WIDF and criticized, for example, the lack of democracy in the preparation of the WIDF's congress of 1963 in Moscow: "I think that while preparing this congress the federation has to review its internal methods of work. I think that we need to bring to our organization, and I want to use this word - to bring in - a democracy"20.

19 State Archive of the Russian Federation (further: GARF), Fond of the Committee of the Soviet Women, fond 7928 opis 4 delo149, p. 142, December 1961.

20 GARF fond 7928 opis 3 delo 790, p. 26, 1962. 
However, as the previous research has shown ${ }^{21}$, in spite of unusually open discussions at the Moscow congress in 1963, the Italian delegation left the WIDF after this congress. The dissatisfaction with internal democracy in the federation could be considered one of the important reasons for this decision ${ }^{22}$.

The tensions between representing women's interests in the best way and acting in the interests and spirit of democracy continued to be present at the WIDF's meetings in a later period as well. For example, the correspondence between the Soviet representative in Berlin and the Committee of Soviet Women in Moscow from 1974 shows how Freda Brown, the Australian communist and the WIDF president in the 19751991, discussed the invitation of the international guests to the Berlin World Congress of Women in 1975 with the Soviet representatives in the federation. The correspondence shows that Brown, recently nominated as the WIDF President, considered it important to invite "also the organizations that we usually do not address as democratic, but that want to participate in the congress". At the same time, according to the letter by the Soviet representative in the Secretariat in Berlin, Brown "was not sure if the representatives of the socialist countries, would be ready to make some concessions" (with respect to participation of "other" organizations $)^{23}$. Thus, it is possible to understand that in spite of many internal conflicts accumulated by the federation to the 1970s, it continued to preserve its image as the "most" democratic organization and was using the rhetoric of democracy not least for ideological divisions between women's organizations worldwide.

Still, in the later years, the federation continued to be criticized by some of its members for the lack of internal democracy and transparency. In particular, strong critique was expressed by the leaders of the French Union of Women (UFF) in the eighties. Indeed, the Union of French Women sent to the WIDF's Bureau a letter expressing its discontent with many aspects of the work of the federation and communicating hope that the next WIDF congress (Prague 1981) would organize discussion around their opinion ${ }^{24}$. The authors of the letter noted many

${ }^{21}$ Chiara Bonfiglioli, Revolutionary Networks. Women's Political and Social Activism in Cold war Italy and Yugoslavia (1945-1957), PhD diss., (Utrecht, 2012).

22 Ibidem.

23 GARF fond 7928 opis 3 delo 3414, p. 276.

${ }^{24}$ GARF fond 7928 opis 3 delo 5077, p. 268-279. 
problems in the work of the federation, including too much attention to the issues of peace and disarmament. According to them, the issues of peace "could not be central (in the WIDF's work) comparing to other issues important for women." However, it was internal democracy in the organization that the Union of French Women paid a special attention to: "we can not join the speeches, texts, resolutions and Federation's positions that are elaborated without broader discussion, without dealing with them democratically". According to the letter, in many cases the documents were prepared by the Secretariat in advance, while meetings of the WIDF council and its congresses were planned by such a way that they did not leave time for serious discussion. Thus, the documents were expected to be adopted without changes (that could result on the base of the serious discussion): "during few hours and sometimes during even a shorter period the council members had to express their opinions about complex projects whose adoption could cause a lot of problems for women of our organization" 25 .

In order to foster a broader democratic discussion about women's rights among the congress participants, the members of the Union of French Women, proposed to use the UN CEDAW convention as a common platform for opening small groups discussions. The issues that could be discussed included: end of discrimination in the legislation and in practice, advancement of women in the sphere of work and education, recognition of the economic role of woman in agriculture, recognition of the maternity as a social function and responsibilities of the parents and of the state, promotion of women's participation in the cultural, economic and political life ${ }^{26}$.

As it is possible to suppose, such a broad and free discussion of the contemporary problems of women's rights most probably, required review of the rights that women had in the countries of the state socialism as well. Thus, the proposal of the French organization obviously was not welcomed by the representatives of women's organizations from the countries of state socialism.

${ }_{25}$ GARF fond 7928 opis 3 delo 5077, p. 273.

26 GARF fond 7928 opis 3 delo 5077, p. 267. 


\section{Women's rights: a part of protection of peace or a part of human rights?}

The idea of "rights" was central for the WIDF's official documents during the whole period of the WIDF's Cold War history. The World Congress of Women in Copenhagen (1953) included keynote presentation by Andrea Andreen, a Swedish medical doctor, peace activist and the WIDF vice-president: "Struggle for the defense of rights of women as mothers, workers and citizens" ${ }^{27}$. At the Moscow congress 1963 one of the keynote speeches also was dedicated to the rights of women in family and society ${ }^{28}$.

Taking into account the problems with the legal issues and rights in the Soviet Union itself, it is particularly remarkable that the federation was using the discourse of "violation of rights", "human rights" and the "rights of women and children" in its official speeches and publications during the whole Cold War period. While according to Samuel Moyn, the "human rights" started to be used by the women's movement quite late, in the 1970 s- 1980 s $^{29}$, the publications of the WIDF show that the countries of the Soviet bloc started to use this concept in their support for women's rights in the colonial and dependent countries as well as in the authoritarian Spain, Greece and Portugal, already in the 1950s-1960s.

During the early 1960s the special bulletin, Pour la defense des droits de la personne humaine, was published in France by the WIDF (in French). The bulletin was dedicated mainly to the rights of women and could be seen as an excellent example of use of the idea of "women's rights are human rights" by the pro-Soviet defenders of the rights of women. The bulletin was thought as a space for expressing solidarity to those women and countries that were seen as having problems with rights and freedom. For example, the issues 1 and 2 from 1962 published a letter from women from Portugal describing the persecution by the fascist regime; the journal also published letters of solidarity with $\mathrm{Cu}$ ban women sent from Mexico, Ecuador, Colombia, Argentina and Costa Rica $^{30}$. The journal articles from 1963 and 1964 contain the materials

\footnotetext{
27 Za ravnopravie, schastie, mir, (Berlin : WIDF, 1953), 9-39.

${ }^{28}$ GARF fond 7928 opis 3 delo 1020, pp.15-17 from 2.04.1963.

29 Samuel Moyn, The Last Utopia. Human Rights in History, (Cambridge : Belknap Press of Harvard University Press, 2010).

30 GARF fond 7928 opis 3 delo 801.
} 
about violations of women's rights in Venezuela, Portugal, Honduras, Spain, Ecuador and South-African Republic (SAR). The materials on the South-African Republic, for example, explained to the readers that power in the country belongs to the "racists" and that they cruelly use it against the black population and black women ${ }^{31}$.

The WIDF also presented itself as acting in the spirit of the UN HR convention. For example, the circular letter from the Secretariat of the WIDF sent by Rosa Jasovich-Pantaleon, the WIDF General Secretary, in August 1963 informed the WIDF member organizations about letter distributed by UNESCO on 15th anniversary of the Human rights declaration that will be celebrated on 10 December 1963. She continued that "WIDF that always was acting on the base of and struggling for the human rights, constantly defended the need of the realization of the declaration in practice and in all the countries"32.

Together to the human rights, the WIDF's vision of the rights of women always was closely connected to the defense of peace and rights of children. For example, the WIDF's President, PhD in Physics, Eugenie Cotton, in her speech at the opening of World Women's Congress in Copenhagen in 1953 brought peace, protection of children and women's rights together. She stated that the delegates of 80 countries has gathered at the WIDF congress in Copenhagen "in order to together find concrete answers to the questions that are important for all the women". These issues, according to her, included protection of peace, protection of children and obtaining and protecting of the rights of women ${ }^{33}$. Cotton insisted on the obvious connection between the wars that endanger the happy future of children while the money spent for the preparation of the war are depriving children from education they need. When women lack rights, this lack of rights often prevent them from acting on behalf of the children. Cotton also stressed that the congress has to show "that more and more women of different believes can understand each other and act together"34.

The combination of goals bringing together values of peace, children and women's rights as well as a need of the creation of an

31 GARF fond 7928 opis 3 delo 1043, p. 43.

32 GARF fond 7928 opis 3 delo 1020, p. 61.

33 Za ravnopravie, 7 .

34 Ibidem. 
organization in order to defend them collectively in one or another form could be found in many WIDF official documents and publications. Indeed the construction of durable peace was seen by the federation as an important condition for happy childhood and for prevention of the suffering of women similar to that in the period of the WWII. The wars could also make many mothers to loose their children who can be killed at the war. That is why, another WIDF leader, Argentinian communist Fanny Edelman, stressed the connection between reproductive role of women and protection of peace: Edelman wrote in her memories dedicated to the 1955 congress of mothers organized by the WIDF in Lausanne that the delegates were sure that mothers "who gives the life, should defend the life" 35 .

It is important to note, that in many WIDF publications the Soviet Union and the countries of state socialism were portrayed as the peace lovers, but it were the Western countries that were producing arms, distributing military bases, tasting atomic weapons and starting military operations. Thus, the WIDF's role was to show the positive intentions of the Soviet Union and to denounce war, weapon production and testing from the side of its Cold War adversaries.

At the same time, at some moments of the WIDF's history, the ideas of rights for women clearly were in a conflict with the WIDF general interests in protection of peace. Arguing against Western feminists focus on rights, Nina Popova, the Soviet representative and the WIDF's vice-president, in her speech at the WIDF's Bureau meeting in 1963 stated that even "old international women's organizations" started to understand that

the focus in activity of the international women's organizations moves from the question about the situation of women and their rights (even if these questions continue to be important) to the issues of responsibility of women and their participation in the life of the society. These organizations can not ignore further the aspiration of women for peace ${ }^{36}$.

35 Fanny Edelman, Banderas, Pasiones, Camaradas (Buenos Aires : Ediciones Dirple, 1996), 142.

36 GARF fond 7928 opis 3 delo 790 p. $72,30.05 .62$. 


\section{Conclusion}

On the base of the studied material it is possible to say that the WIDF showcased the Soviet ideas and practices of emancipation of women as a possible example for women starting to build their independent countries. The experience of the Soviet ethnic and cultural borderlands were shown as particularly useful for this aim. The achievements of other countries of the state socialism also were shown to the readers, in particularly, to those from Asia and Africa, as an important example to follow.

The WIDF also widely used international vocabulary of rights and democracy. In particular, the federation was one of those who started to actively use the concept of "human rights" and had a well developed program of the rights of women, including their political, economic and social rights. However, the use of both concepts - "human rights" and "democracy" - was very limited; it was questioned already during the 1960s, but, in particular, in the 1970s and 1980s both from outside and inside of the organization.

\section{Bibliography}

\section{Sources}

State Archive of the Russian Federation (GARF), fond 7928, Committee of the Soviet Woman.

Women of the Whole World, 1960-1981.

Za ravnopravie, schastie, mir, (Berlin : WIDF, 1953).

Zhenshchiny mira, 1958-1981.

\section{Studies}

Between Protest and Nation-Building, Chen Jian, Martin Klimke, Masha Kirasirova et al. (eds.), (London : Routledge, 2018), 230-242.

Bonfiglioli, Chiara. Revolutionary Networks. Women's Political and Social Activism in Cold War Italy and Yugoslavia (1945-1957), PhD diss., (Utrecht, 2012), https://dspace.library.uu.nl/bitstream/handle/1874/254104/ Bonfiglioli.pdf?sequence.

Djagalov, Rossen. Salazkina, Masha. "Tashkent, 68, a cinematic contact zone", Slavic Review, Vol. 75, No. 2, 2016.

Donert, Celia. "Whose Utopia? Gender, Ideology and Human Rights at the 1975 World Congress in East Berlin”, in: Jan Eckel, Samuel Moyn (eds.), 
The Breakthrough: Human Rights in the 1970s, (Philadelphia : University of Pennsylvania Press, 2014), 68-87.

Edelman, Fanny. Banderas, Pasiones, Camaradas (Buenos Aires : Ediciones Dirple, 1996), 142.

Gallo, Maria Theresa. "Today, a Woman is a President of the Republic of Uzbekistan", Women of the Whole World, No. 2, 1959, 9-21.

Ghodsee, Kristen. Second World, Second Sex, (Durham : Duke University Press, 2018).

Gradskova, Yulia. Soviet Politics of Emancipation of Ethnic Minority Woman. Natsionalka, (Cham : Springer, 2018).

de Haan, Francisca. "Continuing Cold War Paradigms in Western Historiography of Transnational Women's Organizations: The Case of the Women's International Democratic Federation (WIDF)", Women's History Review, Vol. 19, No. 4, 2010, 547-573.

de Haan, Francisca. "The Women's International Democratic Federation (WIDF): History, Main Agenda and Contributions (1945-1991)", in: Thomas Dublin, Kathryn Kish Sklar (eds.), Women and Social Movements (WASI) Online Archive, 2012, http:/ / alexanderstreet.com/products/women-and-social-movements-international.

de Haan, Francisca. "The Global Left-Feminist 1960s. From Copenhagen to Moscow and New York", in: The Routledge Handbook of the Global Sixties, (London : Routledge, 2018), 230-242.

Kamp, Marianne. New Woman in Uzbekistan, Islam, Modernity and Unveiling under Communism, (Seattle : University of Washington Press, 2006).

Kanet, Roger. "Soviet Propaganda and the process of national liberation", in: Roger Kanet (ed.), Soviet Union, Eastern Europe and the Third World, (Cambridge : Cambridge University Press, 1988), 84-114.

McGregor, Katherine. “Opposing Colonialism: the Women's International Democratic Federation and Decolonization Struggles in Vietnam and Algeria 1945-1965", Women's History Review, Vol. 25, No. 6, 2016, 925-944.

Mohanty, Chandra. Feminism without borders: decolonizing theory, practicing solidarity, (Durham : Duke University Press, 2003).

Moyn, Samuel. The Last Utopia. Human Rights in History, (Cambridge, MA : Belknap Press of Harvard University Press, 2010).

Tlostanova, Madina. Gender Epistemologies and Eurasian Borderland, (Basingstoke : Palgrave, 2010). 